University of Nebraska - Lincoln

DigitalCommons@University of Nebraska - Lincoln

To Improve the Academy

Professional and Organizational Development Network in Higher Education

1996

Innovative Teaching and Teaching Improvement

Joyce Povlacs Lunde

Myra S. Wilhite

mwilhite1@unl.edu

Follow this and additional works at: https://digitalcommons.unl.edu/podimproveacad

Part of the Higher Education Administration Commons

Lunde, Joyce Povlacs and Wilhite, Myra S., "Innovative Teaching and Teaching Improvement" (1996). To Improve the Academy. 359.

https://digitalcommons.unl.edu/podimproveacad/359

This Article is brought to you for free and open access by the Professional and Organizational Development Network in Higher Education at DigitalCommons@University of Nebraska - Lincoln. It has been accepted for inclusion in To Improve the Academy by an authorized administrator of DigitalCommons@University of Nebraska - Lincoln. 
Lunde, J. P. and Wilhite, M. S. (1996). Innovative Teaching and Teaching Improvement. In L. Richlin (Ed.), To Improve the Academy, Vol 15 (pp. 155-167). Stillwater, OK: New Forums Press and the Professional and Organizational Development Network in Higher Education. Key words: Innovation, Persistence, Teaching Strategies, Teaching Award Winners.

\section{Innovative Teaching and Teaching Improvement}

\section{Joyce Povlacs Lunde}

\section{Myra S. Wilhite}

University of Nebraska-Lincoln

To discover who innovative teachers are, their practices, and how they might have impact on the improvement of teaching on campus, the authors surveyed 310 faculty on our campus, including recipients of Distinguished Teaching Awards, non-recipients of awards, and newer faculty. Items included sources of ideas, teaching strategies, relating to students, and persistence in making successful changes in teaching. A focus group was selected from those displaying persistence. We believe that innovative teachers are passionate about teaching, persist in its improvement, listen to their students, use active learning adapted to the context, are risk takers, and keep themselves vital. The authors recommend that teaching and learning centers encourage and recognize innovative faculty, helping them become visible as presenters and models for their peers.

In the years since the publication of Involvement of Learning (Study Group, 1984), the portrait of the faculty member as teacher has been undergoing some amazing changes. The stereotype of professor as lecturer is becoming blurred, giving way to something not at all as 
clear, but more exciting and innovative. As instructional consultants witnessing this shift, the authors of this paper believe that identifying the innovative teachers on our campus and finding out what they do is important information for improving teaching. Often teaching and learning centers are criticized for serving those "who don't need it." We disagree with the assumption behind this view that good teachers do not need instructional support. With the assistance of a grant from the Professional and Organizational Development (POD) Network in 1993, we set out to discover who the innovative teachers are on campus, their teaching practices, and the impact they might have on improving teaching and learning at our research institution.

\section{What is Innovative Teaching?}

It is not a simple task to set forth the critical attributes of innovative teaching. Discussions about innovation in teaching, such as many exchanges on the POD Listserv, are based on an assumed common, implicit, definition. Many articles in periodicals such as Innovative Higher Education and College Teaching apply the term either to programmatic changes or to single innovations in specific courses, ranging from incorporating the use of computers in a class for the first time to a novel way of teaching mathematics in groups. It may be more useful to say that the term innovative teaching represents a construct, comprised of a cluster of qualities including effective interaction with learners, openness to change, persistence, reflective practice, specificity of approach, and discipline-embedded pedagogy. Innovative teaching is more than the light bulb that comes on when innovation occurs, more than going where no one has gone before. In a recent presentation, Barker (1995) said that "inventing" is "creating" and "innovation" is valuing, introducing, and using "invention." Those individuals with flash-in-the pan-creativity may be exciting, but innovative teachers more properly include those who are alert to new ideas, forge them into something uniquely their own, test them, and persist until their students are engaged and their teaching is transformed. 


\section{Identifying Innovative Teachers}

Instructional consultants can usually name those individuals on their campuses whom they consider to be innovators, but identifying these individuals in a systematic way is a challenge, or so we discovered. As at other institutions, our campus was experiencing the impact of new technologies in college classrooms and new approaches to active learning. The problem was to identify those who were the innovators experimenting with and implementing fresh approaches in their classrooms.

To gather information about innovative teaching, we decided to use a survey questionnaire followed by a focus group. One group we wanted to include was comprised of recipients of Distinguished Teaching Awards (DTAs). Although the process of selecting individuals for teaching awards has been often maligned as a popularity contest, selection processes on our campus take into account a range of information about teaching, including both peer comments and student evaluations. In addition, we decided to survey a sample of faculty at large, including both experienced and less experienced. The categories surveyed included:

Recipients of Distinguished Teaching Awards in the past ten years ( $\mathrm{n}=\mathbf{8 0}$ )

Non-recipients of any awards, with at least five years of service, randomly selected $(n=160)$

Non-recipients of any awards, with less than five years of service $(\mathrm{n}=70)$.

The total of 310 individuals surveyed represented about 25 percent of our university 's full-time faculty of 1,200.

On the questionnaire, categories of items included identifying sources of ideas (12 items); using a variety of teaching strategies (47 items); relating to students in significant ways ( 20 items); and persisting in making changes ( 3 items). The sources of the items were found in Inventories of Good Practice in Undergraduate Education (Chickering, Gamson, and Barsi, 1989); Active Learning (Bonwell and Eison, 1991), and our own observations. In constructing the questionnaire, our underlying assumption was that innovative teaching would be found in use of more contemporary strategies of active learning, 
in practices that challenge and support students, and in employment of alternatives to traditional lecture. The questionnaire may be obtained by request from the authors.

\section{Innovation in Classroom Practices and Relating to Students}

We received 166 usable responses (53\%) of the 310 surveyed, including 49 of $80(61.3 \%)$ of the award recipients; 82 of $160(51.3 \%)$ of the non-recipients; and 35 of $70(50 \%)$ of the newer faculty (which were later included in the general category of non-recipients).

The assumption that recipients of Distinguished Teaching Awards (DTAs) would be more likely to be innovative teachers than those who never received awards had only mild support in two general areas. We found that DTAs were more likely to engage more frequently in a few innovative teaching strategies and practices, than non-recipients (see Table 1). As might be expected, newer, more specific strategies, such as guided imagery, although used more frequently by DTAs, were rarely chosen by anyone. In general, responses to items on teaching strategies and relating to students suggest

\section{TABLE 1}

Means for How Often Respondent Engaged in Specific Teaching Practices, As Selected by Recipients and Non-Recipients of Distinguished Teaching Awards

\begin{tabular}{|c|c|c|}
\hline & $\begin{array}{c}\text { Recipients } \\
n=49 \\
\end{array}$ & $\begin{array}{c}\text { Non-Recipients } \\
n=117\end{array}$ \\
\hline \multicolumn{3}{|l|}{ Teaching Strategies } \\
\hline asking questions & $1.22^{* *}$ & 1.49 \\
\hline ecture with discussion & $12.14^{*}$ & 2.34 \\
\hline panels of students & $3.57^{\star}$ & 4.16 \\
\hline guided imagery & $4.07^{\star \star \star}$ & 4.48 \\
\hline in-class reading & $4.41^{\text {t* }}$ & 4.68 \\
\hline \multicolumn{3}{|l|}{ Relating to students } \\
\hline mentor/ informal advisor & $1.53^{\text {t* }}$ & 1.96 \\
\hline
\end{tabular}


that DTAs employed student-centered practices more frequently than non-recipients. However, on most items, differences are not significant.

\section{TABLE 2}

\section{Questions Regarding Changes, Persistence, and Success} in Innovation As Selected by Recipients and Non-Recipients of Distinguished Teaching Awards

\begin{tabular}{|c|c|c|c|}
\hline & & $\begin{array}{l}\text { Recipients } \\
n=49\end{array}$ & $\begin{array}{c}\text { Non- } \\
\text { Recipients } \\
n=117\end{array}$ \\
\hline \multicolumn{4}{|c|}{$\begin{array}{l}\text { Question } 91 \\
\text { Which one of the following statements describes the level of } \\
\text { changes you have made in the course of your teaching over the } \\
\text { past five years? }\end{array}$} \\
\hline \multicolumn{4}{|c|}{ Responses } \\
\hline a. & Made no changes in my courses & 0 & 0 \\
\hline b. & Made minor changes in my teaching & $6.4 \%$ & $65.2 \%$ \\
\hline c.* & Made some significant changes in my courses & $74.5 \%$ & $20.9 \%$ \\
\hline d. ${ }^{*}$ & Changed the course and my teaching greatly & $19.1 \%$ & $2.6 \%$ \\
\hline \multicolumn{4}{|c|}{$\begin{array}{l}\text { Question } 92 \\
\text { How successful are changes you made? }\end{array}$} \\
\hline \multicolumn{4}{|c|}{ Responses } \\
\hline a. ${ }^{*}$ & Extremely & $12.5 \%$ & $7.9 \%$ \\
\hline b. ${ }^{*}$ & Very & $52.1 \%$ & $43.9 \%$ \\
\hline c.* & Moderately & $35.4 \%$ & $42.1 \%$ \\
\hline d. & Little & 0 & $6.1 \%$ \\
\hline e. & Not successful & 0 & 0 \\
\hline \multicolumn{4}{|c|}{$\begin{array}{l}\text { Question } 93 \\
\text { If something does not work, how often do you try again? }\end{array}$} \\
\hline \multicolumn{4}{|c|}{ Responses } \\
\hline a. & Do not try again & $6.8 \%$ & $18.2 \%$ \\
\hline b. & Try one more time & $27.3 \%$ & $40.4 \%$ \\
\hline c.* & Several tries & $45.5 \%$ & $29.3 \% *$ \\
\hline d. & Keep trying until it works & $20.5 \%$ & $12.1 \%$ \\
\hline
\end{tabular}

Responses marked * were combined to identify persisters. To be included in the persister category, the respondent had to select one of the responses marked by an asterisk [above] for each of the three items as follows: Question $91 \mathrm{c}$ or $d+$ Question $92 \mathrm{a}, \mathrm{b}$, or $\mathrm{c}+$ Question $93, \mathrm{c}$ or d. 


\section{Persistence, Change, and Innovation}

Too often we hear of faculty members who may try something new, but when the method does not work as expected, quickly drop the idea and return to more traditional teaching. Innovative teaching, we assumed, takes time and work. The questionnaire, therefore, included three items on making important changes, persisting and achieving success. (See Table 2 for questions asked and responses.)

Of the 166 who responded to the survey, $40(24 \%)$ of the respondents fell into the new category of faculty who developed, implemented, and maintained significant and successful changes-we named these persisters - as opposed to those who did not. The persister group included 19 of 49 (39\%) who were award recipients; 14 of 82 (17\%) who were non-recipients; and 7 of $35(20 \%)$ who were newer faculty. Recipients of awards were more strongly represented in the persister group than we expected: of the 40 individuals who reported persistence, 48 percent were award recipients, although they made up only 26 percent of the total sample group of 310 and 29.5 percent of the 166 who responded.

In their responses regarding sources of ideas, persisters were more likely to make use of instructional consultation. They also were more likely to seek ideas from the literature in their field. In responses regarding teaching strategies and relationships with students, persisters tended to select more active learning methods and to relate to students in less formal ways. Asking questions, which might be considered a traditional but essential teaching practice, was also associated with persisters. Although newer, more specific teaching methods, such as "think-pair-share" were used rarely, their use was more likely to be found in the persistent group. See Table 3 for responses and means.

On the whole, those who persisted in making changes reported using active learning strategies more frequently than those who did not. In contrast, the items "lecture with discussion" and "presenting materials," two traditional teaching methods, were more frequently selected by those who did not persist in making changes. 


\begin{tabular}{|c|c|c|}
\hline \multicolumn{3}{|c|}{$\begin{array}{l}\text { TABLE } 3 \\
\text { Sources of Ideas, Teaching Strategies, and Ways of } \\
\text { Relating to Students as Selected by Persisters and } \\
\text { Non-Persisters }\end{array}$} \\
\hline & $\begin{array}{c}\text { Persisters } \\
n=40\end{array}$ & $\begin{array}{c}\begin{array}{c}\text { Non-persisters } \\
n=126\end{array} \\
\end{array}$ \\
\hline $\begin{array}{l}\text { Sources of ideas } \\
\text { readings of literature in the discipline } \\
\text { instructionalffaculty development consultant }\end{array}$ & 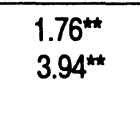 & $\begin{array}{l}2.42 \\
4.10\end{array}$ \\
\hline $\begin{array}{l}\text { Teaching strategies } \\
\text { presenting materials }\end{array}$ & $\begin{array}{l}1.29 \\
1.17^{* *}\end{array}$ & $\begin{array}{l}1.22^{\text {t* }} \\
1.48\end{array}$ \\
\hline asking questions & 2.46 & $2.22^{\text {** }}$ \\
\hline lecture with discussion & $3.42^{*}$ & 3.46 \\
\hline guest lecturers & $4.00^{\text {*t }}$ & 4.61 \\
\hline sensory experiences & $4.00^{* *}$ & 4.69 \\
\hline think-pair-share & $4.02^{*}$ & 4.42 \\
\hline oral quizzes & $4.15^{\text {t* }}$ & 4.74 \\
\hline in-class reading & $4.35^{\text {kt}}$ & 4.78 \\
\hline $\begin{array}{l}\text { service learning } \\
\text { interactive tel./video }\end{array}$ & $4.39^{\text {*t* }}$ & 4.78 \\
\hline Relating to students & $1.48^{\text {*t }}$ & 1.94 \\
\hline mentor/informal advisor & $1.60^{\text {** }}$ & 2.31 \\
\hline Students prepare together for exams & $2.21^{\text {t* }}$ & 2.87 \\
\hline $\begin{array}{l}\text { find out about students and their backgrounds } \\
\text { Call/write students who miss class }\end{array}$ & $3.73^{*}$ & 4.21 \\
\hline \multicolumn{3}{|c|}{$\begin{array}{l}*=\text { significantly different at a } .05 \text { alpha; } \\
\text { ** = significantly different at a } .01 \text { alpha } \\
\text { Scale }=1 \text { very often; } 2 \text { often; } 3 \text { occasionally; } 4 \text { rarely; } 5 \text { never }\end{array}$} \\
\hline
\end{tabular}

\section{Faculty Voices}

The survey questionnaire also asked for comments. Faculty were invited to write "about the most successful, most creative learning activity" they had implemented. Answers to this question ( $n=52$, many of which might be judged to describe innovative approaches to teaching, revealed that innovation can be situational, embedded in the discipline, and even serendipitous. Using technology in teaching, designing group work, and directing undergraduate research or other projects were repeated several times as areas of innovation. One professor described how, for practical reasons, students in a photog- 
raphy class were required to purchase an inexpensive camera. "Beginners are not only less intimated by these cameras," the professor writes, "they are also made to feel more open; there's something about using a less 'serious' camera that encourages them to explore in a way that's more free or loose, and frequently more original."

In addition to the comments gathered on the questionnaire, the focus group of persisters that we assembled also revealed interrelated qualities or characteristics of innovative teaching. The invitation to attend a focus group meeting was extended first to those who were both award recipients and persisters and secondly to persisters on the non-recipient list, with a goal of assembling ten individuals representing different disciplines. After scheduling and other details were worked out, seven faculty (six DTA recipients and one non-recipient), from different departments in the humanities, social sciences, and education, met to describe their practices for us.

\section{Innovative teachers are passionate about teaching}

Comments made in the focus group indicated that participants devote time to being better teachers, are genuinely interested in students, and carefully analyze their teaching. One sample comment:

We're [teacher and students] trying to do some classroom research on forming groups-trying to find out why things are working-why they're not. It's kind of messy for the time being. We're trying to work with a number of different approaches.

They also help students take responsibility for their own learning, usually rely on active learning strategies, create a safe classroom environment, work with their students as colleagues, often measure their success by the success of their students, and seek out colleagues who also value teaching. Sample comments:

In an academic environment you are given a lot of privacy. Idon't like to work in a vacuum.

And:

Part of the motivation in maintaining this cluster of people [a "Teaching Circle" in this person's department] who meet semi-formally to talk about teaching is so that others like me who are doing something, 
can know that other people notice and care about it. I like to have somebody acknowledge that I am doing something. Even when things are going well, I want to talk about them.

\section{Innovative teachers are risk takers}

Members of the focus group do not arbitrarily try innovative teaching strategies, nor does persistence mean being locked into a single approach. More than one admitted to classroom disasters. When things were not going well, they became reflective practitioners, sometimes involving students in the analysis of classroom events. Doing "something different" is not at all threatening. A sample comment:

I like the idea of variability. That's just essential. Doing something wild or different. Sometimes when I'm dying in class, I just wing it and see what happens. Things that are now standard class exercises were things that were tried out of desperation.

\section{Innovative teachers keep themselves vital}

The members of the focus group appeared eager to learn from colleagues, citing departmental brown bags, journaling partners, use of the Internet, and events organized by the university Teaching and Learning Center. They reported soliciting student feedback continuously and view it constructively. A sample comment:

One resource that I've found that has become very important to me the past three years is electronic mail. When you get on different listservs around the country and people start talking about different techniques and I've pulled four, five or six different assignments off different listservs that colleagues across the world have shared. That's a neat thing.

\section{Innovative teachers recognize the need for freedom to learn}

Combining challenge and flexibility can produce a moment of excitement for both the teacher and the student. We asked the members of the focus group to "think of a time when you considered yourself most successful in teaching" and asked them to describe the 
situation and their role in it. The following extended example is heard in the voice of a geology professor in the group.

It happened to me just last week. I teach a senior level class which is a core class in geologic research and it includes some graduate students. I take the group to the Garden of the Gods and teach them how to map in the field. Then I give them one day during this four-day period to pursue any project that interests them. They have to clear it with me, but basically they can do anything even if it's not closely linked to the content of the course. Last week one of the graduate students from Peru, who had never had this course before, came to me excited saying that he took these samples, processed them, broke them down to see if there were any micro fossils and they're full of micro fossils.

I can't find any evidence of this in the literature. It 's previously unknown. This is a new discovery! I want to publish a paper. [The professor quoted the student.]

[The professor continues] Here's a required field trip for a terribly hard course, and this student has turned it into a research project. And I think he's going to get a paper out of it! I just felt so good. The whole class was excited. They all gathered around and looked at his photographs of micro fossils. You could just feel the energy level going up and up right out of sight. I'm still glowing!

This example epitomizes innovative teaching in action. Innovation is obvious in the planning that took the students on a field trip to such a beautiful setting, in providing a challenging agenda, in active learning strategies, and in the excitement and passion of the instructor and the students. The heart of the innovation lies in allowing students freedom to discover at just the right time.

At this point, the inclusive definition of innovative teaching might be judged as being far too inclusive. Are we not describing effective teaching? And perhaps that's the point! Teachers who are not innovative see limitations rather than opportunities in students, facilities, their colleagues and institutions, and in themselves. Instructional consultants (usually the optimists) believe that every teacher has at least some potential to be effective. Therefore, it is vital to support and recognize the work of innovative teachers who are the pace-setters for excellence across our campuses. 


\section{Recommendations}

The innovative teachers in the focus group encouraged us to help keep innovative teaching visible and to continue offering a variety of workshops, even if attendance flags at times. They suggested placing articles in the university newsletter about innovative teaching (perhaps written by individuals known for their research and scholarship), targeting younger faculty to invite to Teaching and Learning Center events, and facilitating discussion across departments.

Based on the comments of the focus group, information gathered from the questionnaire, and our further observations, we offer additional suggestions regarding how teaching and learning centers can encourage innovative teaching.

1. Listening for qualities of innovation noted here, such as persistence, risk-taking, experimentation, and passion about teaching, as we go about our work on our campuses will reveal innovative teachers. Recipients of DTAs are a place to start, but the group will be larger than the obvious award winners. Instructional consultants, however, do not necessarily need a survey to identify innovative teachers.

2. If innovative teachers are to receive distinguished teaching awards, the award system should intentionally focus on characteristics for innovative teaching. Teaching and learning consultants can assist faculty committees in designing or revising award criteria, documentation, and procedures. Evidence presented in teaching portfolios might provide an equitable means of judging such awards.

3. Teaching and learning center events do provide a meeting place and a source of new ideas and materials for innovators. These faculty especially value the opportunity to find out what is new and to meet colleagues across the disciplines.

4. Innovative teachers can be invited to be panelists, workshop presenters, and resource persons. This practice leverages a center's resources, makes innovations visible, and provides peer models to other faculty. For those faculty who contribute in this way, a small amount of funds ( $\$ 50$ - $\$ 100)$ for professional development acknowledges their contributions. A flyer listing faculty who had appeared on programs is another way to recognize innovators. 
5. Teaching and learning centers need to continue providing the intersection between discipline-specific and more general approaches to improving teaching. Innovations springing from a discipline might be shared across the institution, while general workshops on topics ranging from learning technologies to small groups in the classroom can be applied to the discipline.

\section{Conclusion}

Innovative teachers and faculty developers need each other. Instructional consultants in teaching improvement centers are the cheerleaders and reinforcers of those who bring inventiveness into their teaching. Innovative teachers are advocates and models of effective teaching.

To add "the rest of the story" to the extended example above: recently, one of us met the geology teacher from the focus group at a learning technologies workshop. She and her colleague were experimenting with a software program to develop a vivid portrayal of a volcanic eruption. At one of the workshop breaks, she demonstrated the use of a Star Trek badge she was wearing. When she tapped it, a few clear notes sounded, which, she said, she used to call small groups back to attention in her classroom. Now why didn't we think of that?

\section{References}

Barker, J. (1995, October 2). How to introduce new ideas to people who don't want them. Presentation at the Mid-Regional Quality Conference of ASQC, Lincoln, NE.

Chickering, A.W., Gamson, Z.F., \& Barsi, L.M. (1989). Seven principles for good practice in undergraduate education: Faculty inventory. Racine, WI: Johnson Foundation, Inc. Wingspread.

Bonwell, C.C., \& Eison, J. A. (1991). Active learning: Creating excitement in the classroom. Report One. ASHE-ERIC Higher Education Reports. Washington, DC: George Washington University, Clearinghouse on Higher Education.

Study Group on the Conditions of Excellence in American Higher Education. (1984). Involvement in learning: Realizing the potential of American higher education. Washington, DC: National Institute of Education. 


\section{Contact:}

Joyce Povlacs Lunde

Department of Agricultural Leadership, Education \& Communication

University of Nebraska - Lincoln

300 Agricultural Hall

Lincoln, NE 68583-0709 USA

(402) 472-2174

(402) 472-5863 FAX

jlunde@unl.unlvm.edu

Joyce Povlacs Lunde is an associate professor in the department of Agricultural Leadership, Education and Communication and an educational development specialist in the Office of Professional and Organizational Development at the University of Nebraska - Lincoln.

Myra S. Wilhite is a faculty instructional consultant at the Teaching and Learning Center and an associate professor in the department of Agricultural Leadership, Education and Communication at the University of Nebraska - Lincoln

The authors acknowledge the work of Larry Andelt, Ph.D., Director of Life Skills Program, Nebraska Department of Correctional Services, who as a doctoral student assisted in the input and management of the data and preparation of tables displaying results. 